\title{
ERDÉLY I TUDOMÁNYOS FÜZETEK
}

175. $\mathrm{SZ}$.

\section{KÖZÉPKORI TEMETŐINK FELTÁRÁSMÓDJÁRÓL}

\author{
IRTA \\ MÉRI ISTVÁN
}

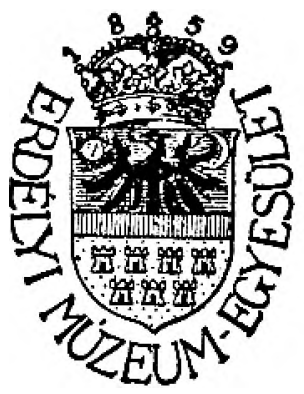

KOLOZSFAR, 1944

A Z E B D É L Y I M ÜZ E U H - E G Y E S ÜL E T K I A D A S A 
ban összefüggések megrigyelése. $\mathrm{E}$ megfigyeléskor azonban arra kell törekedni, hogy az ne csak jelenlegi érdeklödési körünknek megfelelö rớgzítés, hanem az összes megfigyelhető jelenségek egyenlö értékü felvételezése legyen. $\mathrm{Az}$ ásatónak tehât munka közben minden mozzanatot és jelenséget figyelnie és pontosan rögzítenie kell, mert ha egy ásónyommal lennebb halad, a felső rêteg összes jelenségeivel együtt visszavonhatatlanul eltünik.

Megnehezíti a muskát az, hogy sok és esetenként különböző adottságokkal kell számolnja annak, aki a mult emlékeinek hiteles feltárására vállalkozik. İgy elsósorban a feltárásra kerülö emlékek természete álítja más és más követelmények elé az ásatót. Más ugyanis egy temető és más cgy telep feltárásának módja. Ez az elkülönítés korok szerint és azokon belül tovább is folytatható (öskori telep, középkori falu, vár; óskori, népvándorláskori temető́ csontvázas, urnatemeikezés, stb., stb.). A feltáráskor a talajkiilönbségek is a munka menetének esetenkénti módosítását kivánják. Másként kell dolgozni köves, agyagos, homokos, ${ }^{3}$ stb. területen. A terepalakulatokat is figyelembe kell vennie a kutatónak (sík terïlet, hegyoldal, stb.).

Mindezek azt eredményezik, hogy az általános ásatási alapelveket szinte minden esetben alkalmazni kell a helyi adottságokhoz. Nem beszélhetünk telzát egy minden korra és minden helyzetben érvényes ásatástechnikârôl.

$\mathrm{Az}$ elözö korok telepeinek és temetöinek rendszeres feltárása nagy multra tekinthet vissza. Az ása tások hosszú sora járult tehát hozzá az ásatástechnika módozatainak kialakításához. Magyarországon a középkor falvainak és azok temetóinek légészeti feltárása viszont csak az utolsó évtizedekben indult meg. $\mathrm{Ez}$ a munka olyan követelményekkel találta magát szemben, amelyeknek legyözéséhez nem elegendők a korábbi telepek és temetők feltárásakor szerzet tapasztalatok és kialakult ásatási módszerek.

A saïkségesnek mutatkozó különleges ásatási munkamenet kialakításának fontosságát növeli az a körülmény, hogy az Arpád-kori magyarság mindennapi életének kutatásában az e korbeli temetőknek rendkivüli jelentósége van. Amig az elsó magyar századokból nem ástunk fel települést, ez az egyetlen tárgyi adattár, amelyböl kiformálhatjuk az egykori magyanság óletmódjăt. Szerencsére a temetök s általában a halottal való bánásmód egy-cgy társadalom gondolkozás- és életmódjára igen jellemzöek, s így még a leletekben szegényes sírok is beeses segitséget jelentenek a munkában.

Említettem, hogy középkori temetöink más jellegüek, mint az előző korokból feltárt temetkezések. A korábbi temetók képe, még ha korban évezredek választják is el ôket egymástól, egyöntetüek abból a szempontból, hogy egymásra temetkezést csak nagyon ritkán találunk. Több-

${ }^{3}$ Értékes gyakorlati útmutatást nyújt Szabó Kálmain közleménye (Folia Archaeologica III-IV, 286-7.) kisebb leleteknek, föleg a földmunkíval feldúlt síroł apróbb mellékleteinek homokból való összegyũjtésére (Rostarendszer). 
féle oka van ennek, de az okok valamennyije végsö elemzésben a temetkezơ nép élet- és településmódjában gyökerezik. Ėzek a temetök ugyanis mindig a településen kívül vannak, s igy határuk használatukkor a szükséghez mérten tágítható volt. Ennek kờvetkeztében egészen a középkorig rendszerint egyrétegü temetőket találunk, amelyekben a sírokat cgymástól bizonyos távolságra ásták. Feltárásukkor tehát nagy vonásokban egységes szempontok érvényesíthetôk.

Az ilyen temetök ásatásakor - akár kutatóúrkos rendszemel, akár egymáshoz csatlakozó szelvényekben tảrjảk fel ỏket - a sirok egymástól függetlenül, olyan sorrendben bontlıatôk, amint az ásatás soran a szelvény más-más helyén bukhannak rájuk. Egy-egy sír tehát jelenségeivel együtt külön-küilön rögzithetö (rajzolás, leírás) anélkül, hogy 'záltal a temetỏ összképének kialakulását megzavarnák.

Ezzel szemben a középkori temetök a templom körül, rendszerint a tejepülés központjában voltak s így határuk a község kialakulása során megszabott területre korlátozódott. Az Arpád-házi királyok alałt törvények," majd mikor ezek jelentỏségiiket vesztették, a begyökeresedett hagyományokhoz való ragaszkodás késztette a lakosságot arra, hogy szinte a jelenkorig a terjeszkedés lehetôségétöl megfosztott templomkörüli cintermet használja temetkezési helyül." İgy a körülmények kényszerítő hatására bizonyos idöközökben a temetỏ elhagyot részeibe újra meg újra temetkeztek, aminek az voit a következménye, hogy az újabb temetkezésekkel a régilbb sírok egy részét mindig megbolygatták. A középkori temetökben tehát a sírok összezsúfolva, különbözö szintekben vannak s így többségïk részben, vagy teljesen bolygatott. ${ }^{\circ}$

A többrétegú, egymást átmetszö és szétdúló sírok tơmkelegébỏl kell

4 Lásd Szent László (I. 25.) és Kälmán (I. 73.) idevonatkozó törvényét. - Vö. Závodszky értelmezését: $A$ Szent István, Szent Lúiszló és Kálmán korabeli törvények és zsinati határozatok forrórai. Budapest, 1904. 92 .

5 A legtöbb esetben tehát nem beszélhetünk zárt középkori temetöröl, hanem ugyanúgy, mint az alább ismerteteudö kidei temető esetében is, a XIX. századig állandó temetkezések bolygathatták meg a temető régebbi rétegét. - Csak a mult század vége felé korlátozza türvéng a templomok körüli temetkezéseket. A közegészsćgügy rendezéséröl szóló 1876. XIV. t. c. 120-121. \$-a értelmében a värosok belterületén épülö új templomok körül sírkertek nem létesíthetök; az olyan régibb templomolban és azok körül levó sírkertekben, melyekben a temetkezés addig szokásos volt, esak abban az esetben temetkezhetzek továbbra is - hatósági engedéllyel -, ha a temetkezés a közegészségi érdekeket nem sérti. - Ez a törróny úgyszólván csak véglegesítette azt az újabbkori szokást, hogy a temetőket a városok és falvak peremére telepítették ki.

${ }_{6}$ Ez természetesen nem vonatkozik olyan középkori telepälésekre, ahol az élet, 8 így a temetkezés folytonossága is, valamilyen külső, vagy belsö ok következtében rövid idố multán vérlegesen megszakadt. Ilyen ok például a falu elpusztulása. Az állandó ellenséges dúlás következtében sok olyan falunk pusztalt el, melynek helyćn lkésőbb nem keletkezett ńjabb település. Más okok is hasonló eredmény re vezettek. Igy például ha a falu lakossága a közelben levö yárosba költözött, $\mathrm{s}$ így a falu lassan elnóptelenedve pusz" tulásnak indult. 
nz egyes sírokat kíséröjelensógeikkel együtt kihámozni. Ez pedig csak az összefüggések láncolatínak pontos megfigyelése és lerögzitése által lehetséges. Ez már naagában is megszabja, hogy a középkori temetók fellârása közvetlenuil egymásmellé esatlakozó szelvónyek földjének teljes kitormelésével lehetséges, alol tehát az ásatási terület határain beliil egy talpalatínyi föld sem marad kiásatlanul. A kutatóárkos rendszernól az egyes árłok között kihagyott, tehát kiásatlan földsávok az ásatás területét darabokra tagolják $\mathrm{s}$ ezáltal az összefüggések kihámozását meggátoljảk."

Még egy lényeges kïlönbség van a korábbi és a középkori temetök között, melynek oka a keresztêny túlvilág-szemléletnek a pogányéval homlokegyenest ellenkezö felfogásából fakad. Ez a felfogás a sírokban is vìsszatükrözödik. A pogányságnál a halál az élet túlvilági folytatásának kezdetét jelenti. Ezêrt a halott mellé rakják mindazt, amire annak a túlvilágon szüksége lesz. Emitt a halállal a test megsemmisül, s csak a földi dolgoktól megszabadult lélek él tovább: a halottal - a magyar keresztény korszaknak föleg elsỏ századaiban -- úgyszólván semmit sem temetnek el.

A korábbi temetók sírjai tehát általában korhatározó Jeletekben gazdagabbak. Egy-egy sír mellékletei nemcsak annak korát szabják meg, hanem belölük az egész temetö korára is következtethetünk. A temetố korának nélhány sír mellékleteibỏl való megállapítása annál inkább lehetséges, mivel e temetỏket általában sokkal rövidebb ideig hasznâlták, mint a középloriakat, tehát a sírokat korban aránylag nem nagy idớköz vảlasztja el egymástól.

Mint említettem, a középkori sírok leletekben szegényesek. Sokszor a melléklet nélkïli sírok egész sorozatára bukkanink. Azonkíviil

7 Ezt egy más jellegü temetö feltárásakor személyesen tapasztalt példával szeretrém megrilựitanj. Abbau az idöben, mikor az első ásatásokon vettem részt, évtizedek hagyomúxyakint kutatóirkos módszeriel ásattam a egyik avar temetóben. A kb. $60-80 \mathrm{~cm}$ vastag humuszréter alatt szinte kó. keménységü sárga agyagos talaj következett. Az aránylag mély (150-2501) m) sinok határa ebben a földbell élesen kirajzolódott. Az eryik arok faliban n sirok között egs sekélyebb múlysígü, de sokkal nzalesebb bevágást figyeltem meg, mely az agyagos talajba alig $15-30 \mathrm{~cm}-\mathrm{re}$ nyúlott bele. Ennek okát kutatva a bevảgús egész tertiletéról ellányattan a földet. A feitárás során egy nagyjuból négyszögletes, vízszintes aljú gỏdör alakult ki, melybe fejvagy lábfelöli végével több sín nyilott bele. Ez a gödör tehá az említett sirokat összekötötte $s$ ezáltal mintegy egységbe fogta. Közepén es sarkaiban tüzelési nyomok között edényeket és edényeserepeket találam. - Kétségtelen, hogy itt halotti szertartás (vagy szertartások) helye ès emlékei maradtak fenn. Ha történetesen a bumuszréteg alatt nem világos agyag következik, vagy ezt a gödröt nem ássák az agyagig, a kutatóárkos rendszer miatt a leírtak nem kerültek volna napfényre. Hány hasonló jelenség maradhatot megfigycletlenäl a fenti ásutási módszer következtében: - Kétségtelen, hogy e módszernek is megvan a maga jelentösége, alkalmazásának helye és ideje olyankor, amikor nem nagyobb összefüggő terület feltárásáról van szó. Például telep hitelesítésekor, ásatás kezdetén a sírok fekvésének, épületromoknál a falak iránýanak megállapítasakor, stb. 
az egymásra zsúfolódó temetkezések következtében olyan sírok feküdhetzek egy szintben, egymás mellett, melyeket korban négy-öt évszázad választ el egymástól. Egy-egy sír telát önmagában nem határozza. meg a temető korât, söt a leletszegénység még az egyes sírok közelebbi meghatározásának lehetóségét is erósen korlátozza. A középkori tometök szerkezete és a síroknak leletekben való szegénysége tellát egyaránt szükségessé teszi, hogy a sírokat összetügrésbon tárjuk fol.

Ezek a jellegzetességek már nagyjából megszabták az Erdélyi Tudományos Intézet kutatómunkája kẹetében a kidei temetó feltárásakor követendö eljárásokat. A kơvetk zökben a fenti vázlatba illesztettem bo megfigyeléseimet, az adott körïlmények között szükségessé vált s az általánostól többékevésbbé ellérö gyakorlati megoldásaimat.

A kidei ásatás ter ỉ letérö́l. Az ásatás a templon mellett két helyen folyt: a templom elótt $9 \times 9.5$ m-es nyugat felé erósen lejtố területen és a templom mögött $3 \times 5.5 \mathrm{~m}$-es nagyjából sík területen. Az elöbbit négy egymáshoz csatlakozó szolvényben tártuk fel, az utóbbi egy szelvény volt. A két ásatási terïlet helyzetét teodolittal a tomplomhoz mértem be. ${ }^{8} \mathrm{Az}$ egyes szelvényeken belïl a méréseket a szokott módszerek egyikével végeztem. A szelvény két, egymásra merőlegesen álló oldala mellett zsineget huzattam ki s az egyes pontok távolságát mindkét oldaltól bemértem (koordináta rendszer).

A felszíni nyomok alapján a templom körül középkori temetöt vártunk, s csak az ásatás folyamán derült ki, hogy ide a XII. századtól a XIX. századig szakadatlanưl temetkeztek. A sírok száma tehát a területhez viszonyitva igen nagy volt: A templom elött 83 , mögötte 33 sít tártunk fel, nem számítva a teljesen széthányt sírok nagy tömegét. A tometkuzési rendszer' következtében a feltárt síroknak is több, jint a fele bolygatott volt $\mathrm{s}$ amellett a hányott csontok szinte áttekinthetetlen összevisszaságából kellett óket kihámozni.

A temetö feltárásának nehézségeit más tényezók is növelték. A templom elótti ásatási szelvényekben a laza földréteg alatt $\mathrm{kb}$. $80-$ $160 \mathrm{~cm}$ mélységben nyers sziklaréteg volt. A sírgödróket néhány livételével o réteg szintjéig ástak. $\mathrm{Az}$ az eset állott tehát înn, hogy helyenként XII. századi sírok XIX. századiakkal egy szintben fokujdtek. Ígymásra temetkezést az ásatási szelvényuek esak a keleti f'clében triláltunk, ahol a felsó földréteg vastagabb volt és természetesen a templom mögötti szelvényben, ahol sziklás ı'étegra a legmélyebb sirok szintjében sem bukkantunk. A helyzet összebouyolításához az is bozzájárult, hogy a sírok korhatározó leletekben - ami ilyen korú temetókvél álłalános - igen szcgényesek voltak. Jóformán csak minden tizedik sírban találtunk mellékletet $\mathrm{s}$ ezek egy része még csak nem is volt korhatározó. Ezekhez járult még az is, hogy a csontvázakat az agyagos föld rosszul konzerválta s amellet még tekintélyes részïket kötörme-

8 Minthogy a temetónek ez alkalominal csak egy részèt tártuk fel, s az ásatás folytatására esetleg esal lyosszalty idö mulva keriilhet sor, e rögzítés pontosságára igen nagy gondos fordítottuk, hogy az eddig feltárt területek határa könnyen és biztosan megtalálható legyen. 


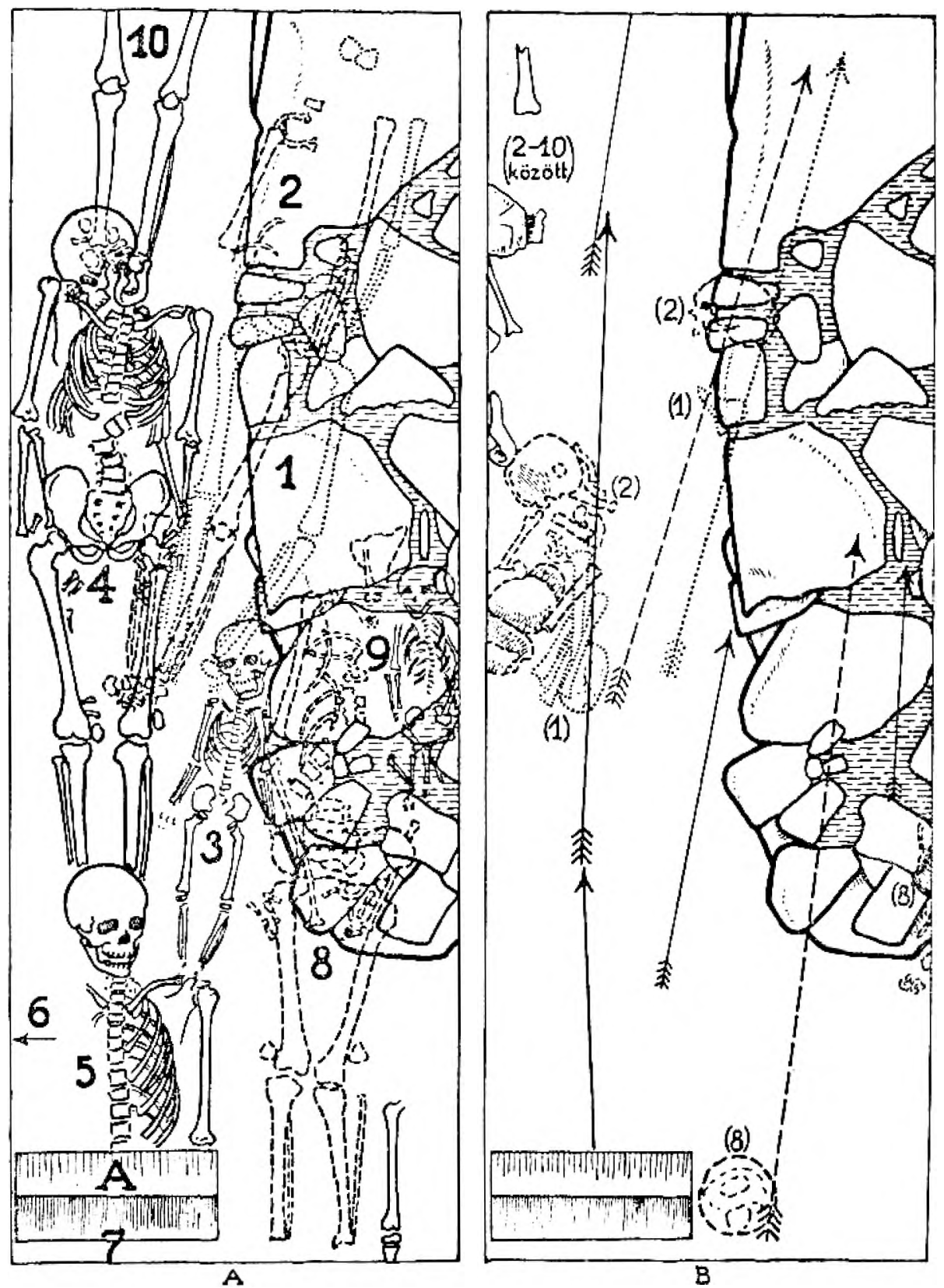

1. kêp. Részlet a kidei temetöből A. Csoutvázak B. Szétbolygatott csontok 
lékbül kellett kihámozni. Végül meg kell még említenem azt, hogy a sírok között egy négyszögletes $(4.5 \times 4.5 \mathrm{~m})$, egy méter falvastagsàgú épitmény alsó alapkoveire is rábukkantunk, melyek a régibb temetkezések egy részén állottak. Sírok tehát nemesak mellettük, hanem alattuk is voltak.

A sírok kibontásáról általánosságban. Az említett köriullmények a sírkibontás munkamenetének új módjăt tették szükségessé. Legtöbbször nem egyes sirokat tártunk fel, hanem egymással terülotileg összefüggö sírcsoportokat bontottunk ki egyszerre. Ez a módszer a munkát kétségteleniil megnehezítette és meglassította, viszont a sírok, illetöleg esontvúzak egymáshoz való helyzeti és idobbeli viszonyának megállapítását nagy mértékben elösegitette, $\mathrm{s}$ ezáltal a feltárt területen a temetkezések teljes képének könnyebb áttekintését tette lehetövé. Tlyenformán az egymást metszö sirok egy-egy esoportjăr végiglaaladva legtöbbször legalább is hozzávetölegesen sikerült a melléklot nélkiili sirok korát is rögzitenünk. Például elöfordult, hogy a leletek alapján az irpád-korböl keltezhetö sírtôl az egy szintben fekvö s egymást megbolygató sírok láncolatán keresztiil egy szintén 'eletekkel meghatározott XVIII. századvégi sírig jutottunk. A kéf megszabott korú sír között a küzbeesö melléklet nélkuiliek korát is kikövetkeztethettuk.

Az 1. képen a temetố térképénck egy kis részletét mutatom be (A), amelyen a temetkezések egymásutánja jốl megfigyelhetö. A bomutatott sirok egy része a fennebb említett kỏalapozás alatt feküdt (1-2, 8-9). Az egymás fölött fekvó esontwáakal alig nóluány em-es földréteg választotta el egymástól. A sírok az alábbi sorrendben kïivetkeznck egymás után. Legkorábbi temetkezés az 1. számmal jelölť (a váz körvonalai pontozottak). ${ }^{9}$ Arpád-kor'i hajkarikák szabták meg korát. Utána a 2. számú következik. A halottat közvetleniil az elöbbirc temették rá. úgyhogy annak koponyảját a sír megásásakor le is vágtâk; csak néhány töredék maradt meg belöle. A 2. sír csontváza is bolygatott; koponyáját a köalapzat készítésckor ásták ki, míg joblo oldalát a 4. sír ásásakor bolygatták meg (jobb felkarcsontja másodlagos fekvésben van, alkarja, medence- és combesontja hiányzik). A 3 . számú gvermekváz részben a 2 . fölött fokszik, tehát korban utána kövelkezik. Erre viszont a 4. halottat temették rá. $\mathrm{Az}$ utóbbi lábszârát boka fölött a következó (5) temetkezéskor vágták el. A két utóbbi nagyjábốl egy szintben fekszik. Az 5. sîr vázánaḱ jobb felét (kar és bordák) szintén újabb sírásáskor vágták el (ez a sír - $6 .-$ a kimetszett szelvénylészletböl kiesik), míg a megmaradt rószét könyöktöl lefelé a korban legfiatalabb tenetkezés allialmával vágták le. $A z$ utóbbi sír ( 7 ) teljes terjedelmével kiesett az ásatási szelvényböl s így nem bontottuk ki. MegJevö sírkövén $(A)$, bár erơsen rongált felületü, többek között 17. évszámot olvashattunk ki, telaát a halottat a XVIIT. században temették c1.

9 A képeken bemutatot sirokat h́gy sxámoztam be, hogy liözöttük az eligazodúst lehetöleg megkönnyitsem. A számok tehát nem egyeznek azokkal, molyeket e sírok a feltárás során kaptak. 


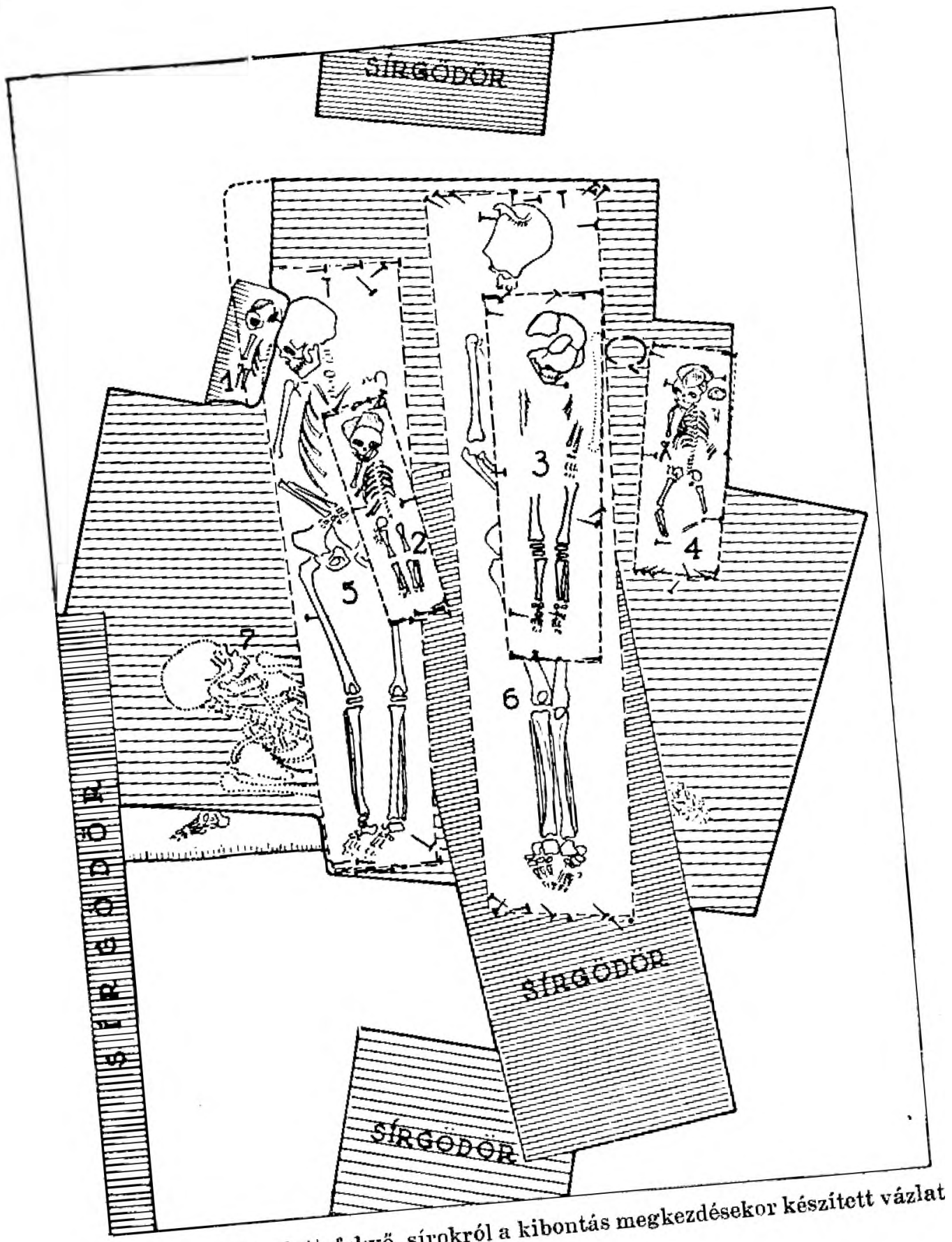

-

2. kép. Egymás alatt fekvö sírokról a kibontas megkezdét 


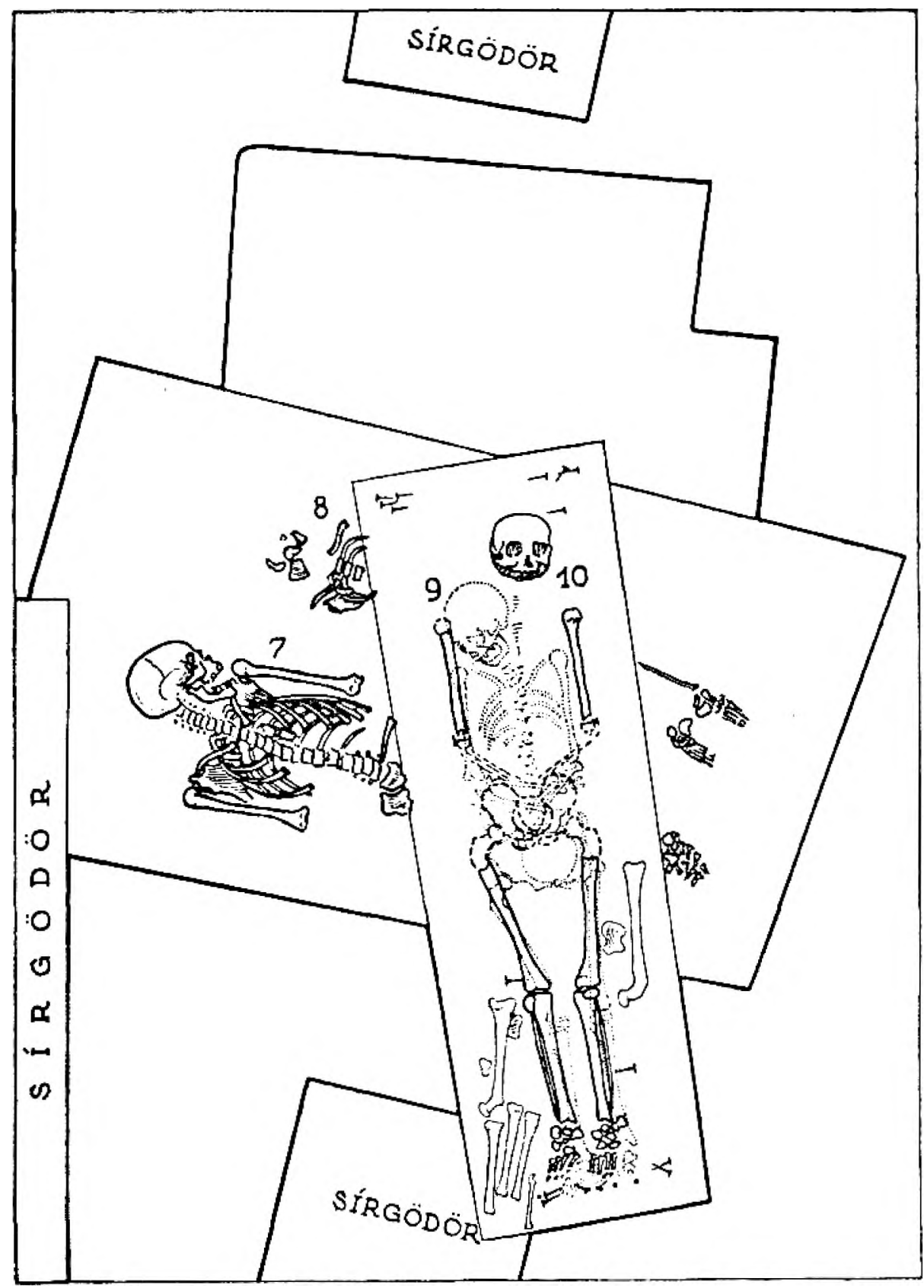

3. kép. A 2. képen bemutatott sircsoport legalsó sírjának kibontásakor készitett vázlat 
A többi sírok a leírt rundszerloe a következóképpen illeszthetök be. A 8 . csontváz jobb oldalát a vele nagyjából egy szintben fokvő 3 . sírral részben megbolygatták (az alkaresontok rendetleniü fekszenek), tehát korban annál idoósebb. A 9 . csecsemö sírjának ásásakor a 8 . váz felső részének bal oldalát a koponyájával együtt széthányták (a koponya belyén a bal lapockacsont feküdt); a 8.-nál tehát későbbi temetkezés. A 10. váz lábfejesontai a 4. koponyája alá nyúlnak, vagyis a 4.-nél korábbi temetkezés, viszont sírgödre ásásakor a 2. váz jobb felét megbolygatták, annál tehát késöbbi. A legkoräbbi (Arpád-kori) és legkésőbbì, XVIII. századi sír kivételével a többi korllatározó adatot nem szolgáltatott.

A bemutatott szelvényrészben a földréteg vastag volt $s$ igy a temetkezésekkor a sírgödröket e szakaszban aránylag elég mélyre áshatták, anélkuil, hogy a korábbi sírokat meg kellett volna zavarniok. Ezért alakulhatoté ki itt a sírok egy rószének nagyjából bolygatatlan egymásfölöttiségo (1-4, 10. sír) s ezért találtunk itl a többi részhez viszonyítva aránylag kevesebb széthányt csontot. $\mathrm{Az}$ utóbbiakat külön mutatom bo azért. hogy az amúgy is zsúfolt esontvázak áttekintését ne zavarják (1. ké p B; a nyilak az elöbb leírt esontvázak hossztengelyét, a bolygatolt csontok mellé ínt számok pedig azt a sírt jelölik, amelynek szintjébốl elökeriiltek). $\Lambda$ két kép egyiuttese adja a temetö szerkezetének teljességét.

Mivel a síroknak egynáshoz való viszonyában a legnagyobb változatosságot tapasztalhattuk, természetesen a fenti eljárást nem mereven, hanem a helyzetszabta körülményeknek megfelelöen rugalmasan alkalmaztuk. Például egyes sícokat is tártunk fel külön-külön, ha azok a többiekkel kapesolatban nem voltak; egy-egy sírcsoportban az egymás alatt fekvö sírokat is egymás után kellett kibontanunk, viszont hat-nyole sír együttes kibontása is eloffordult.

A sírok rajzolása. Az eddigiekböl következik, hogy fokozott fontossága volt annak, hogy a sirok részletes leírása mellett összefüggésüket megfelelőképpen ábrázoljuk is. A sírvázlatok elkészítésének mintájául a Lúszló Gryulától bevezetett és rendszeresîtett sirlapokat vettem; ezek szerkezetükböl következö könnyü és egyszerü kezelés melletł kiválón alkalmasak a sírok képémek megelevenitésére. Az alapgondolatot tehát megtartva, csak az ábrázolásmôd rendszerén változtattam. Ezek a sírlapok ngyanis egy-egy sír szemlêltetô bemutatására szolgálnak, a kidei temető̉ben viszont legtöbbször nem egyes sírokat, lıanem olyan sírcsoportokat kellett felvázolni, amelyek egymással vízszintesen (egymásmellettiség), vagy függöleges irányban (egymásfölöttiség) valamilyen kapesolatban voltak.

A vázlatok készítésekor mindig azt a megoldást választottam, amely az adott belyzetben legmegfelelöbbuek látszott arra, hogy az összefüggések egymấsutánja könnyen követhetỏ legyen. $\mathbf{E}$ vázlatkészítẻs módozatainali latárai azonban annyira egymásba olvadnak, hogy esetenkénti alkalmazásukra szabályokat felállítani nem lehet. Éppen ezért esak nagy ronásokban körvonalazhatom az alkalmazott munkamenet változatait. 
Az egyes szelvényekben talált nagyobb siresoportoknál általában kétféle megoldást alkalmaztam. Egyik esetben a síresoportot esak nagy vonalaiban vázoltam fel egy lapra, hogy a sírok összeftuggését érzékeltessem. Azután a beszámozott sírokat külön-küilön sírlapra vettem részletes rajzukkal és leírásukkal együtt. Ezt a rögzítésmódot többnyire akkor alkalmaztan, ha a esontvázak egymás fölött fektidtek s medlékletük volt. Arra törekedtem, logy a kïlon lapra rajzolt sír környezetébe minél könnyebben beilleszthetö legyen. Ezért gyakran annak sírképén a felette levó rétegbỏl felszedett ráz körvonalait is jelöltem halványan, vagy az alatta mutatkozó másik sírgödörnek, vagy a csontváznak láthatô részzeit is feltüntettem.

A most leírt munkamenetet két példával szemléltetem. A $2 . \mathrm{k}$ épen az egyik siresoportról a kibontás megkezdésekor készitett vázlatot mulatom be. A sírgödröknek eeth az egymásba olvadó külsó határvonala rajzolódott ki. $\mathrm{Az}$ egyes sírok határát a koporsószegek s némileg a koporsódeszkák maradványai mutatták. Legfẹül gyermekek fekuidtek $(i-4)$, ezek alat ḱt két felnött $(5-6)$, míg lennebb már kibontakozóban volt egy keresztben fekvó következö esontváz. A 3 . k é p az elölbbi síresoport legalsó (10) sírjának kibontásakor készített sírvázlatot mutatja. Ugyanabból a sírgödörból már egy másik csontvázat (9) is kicmeltünk (pontozott vonallal jelölve). A \%. és 8. sir magasabb szintben feküdt $\mathrm{s}$ így ezeket a sírgödör ásásakor keresztülvágták. Az ekkor kiásott csontjaik egy részét a sírgödör jobb alsó sarkába, a koporsó melló dobták.

A másik esetben az egész síresoportot rajzban véglegesen egy lapra rözzítettem, s az egyes sírok adatait több hozzáfüzött lapra írtam. Fóleg akkor jártam így el, amikor a csontvázak nagyjából egy szintben feküdtek s leletekben szegények voltak. Ilyen sírok vázlatát ábrázolja a 4 . kép A. A számozás a temetkezések egymásutánját mutatja. A 6. számú esontváz többi lészét is levágták egy következö temetkezéskor. A sírok szintjében fekvố bolygatott csontokat vékonyabb vonallal jelöltem. Ilyenkor is elöfordult, hogy a csoportból egyes sírokat kiiön rajzban kiemeltem. Például ha a csontváz koporsóban feküdt, mellékletei voltak, vagy körülötte sok bolygatott csont volt, stb. Ha egy hosszabban összefiiggö síresoportot két iészletben kellett ábrázolnom, a másodikon az elözóböl a fojytatásként esatlakozó utolsó sírokat újra feltüntettem, hogy a folytonosság követhetö legyen.

Sokszor a sírok zsúfoltsága is szükségessé tette egy-egy részlet kiemelését, de ilyenkor is a környczetével együtt rajzoltam azt le. Azok a csontvázak, amelyek a többiektöl elkülönülve feküdtek, természetesen szintén külön lapokra kerïltek.

Ezek a vázlatok a temető összesíteté térképének megrajzolásakor is nagy segítsćget jelentettek. A helyszínen készitett térképre az ilyen szerkezetü temetóknél minden kis részlẹtet rávetíteni lehetetlen, viszont a részleteknek sokszor igen nagy jelentöségük van.

A teljesen szétbolygatott sírokkal kapesolatos meg $\mathrm{fig}$ y elés ok. A temetö rendszerébe a széthányt csontok is beletartoztak $\mathrm{s}$ igy kibontásukra és rajzolásukra ugyanolyan gondot for- 

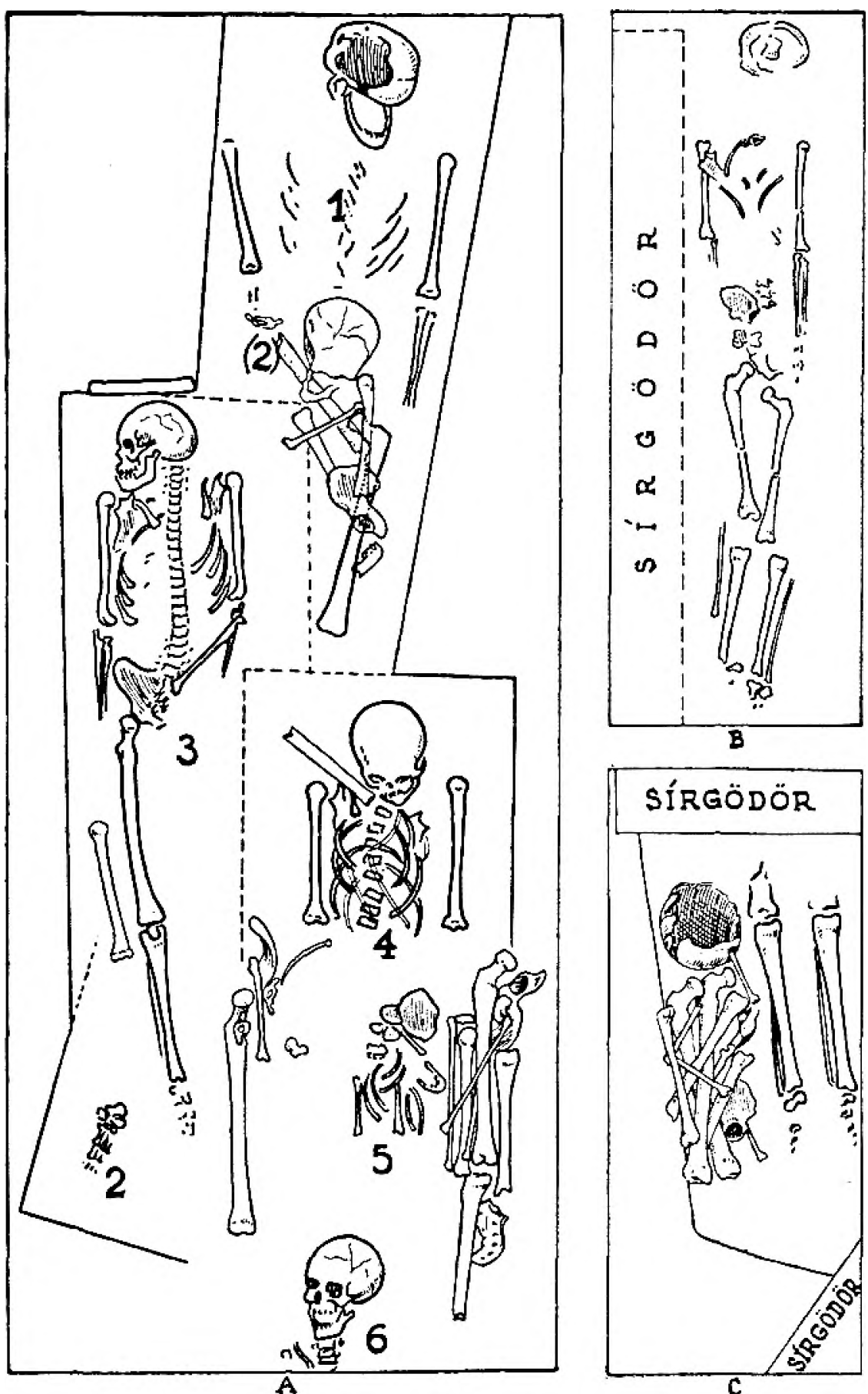

\section{SÍRGÖDÖR}

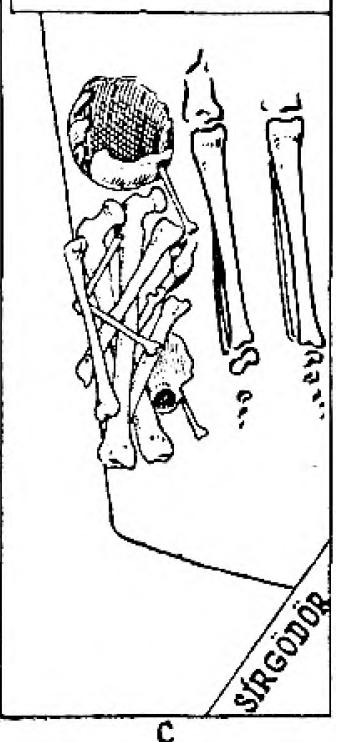

4. Kép. A. Egy szintben fekvö és egymást metszó sfrokról készített vázlat $B$. Uj sírgödör ásásakor keskeny helyre szorított régibb esontváz C. A sírásáskor talált csontok a lábszár mellé egy csomóba rakva 
ditottunk, mint a rendes sírokéra. A feltáráskor már csak azért is fokozott gondossággal kellett dolgoznunk, mivel sokszor igen vehezen ismerheltiik fel azt, hogy a nagy összevisszaságban mely csontok feküsznek bolygatatlanul s melyek a bolygatottak. $\mathrm{Ez}$ a munkamód tette lehetövé, hogy még a teljesen széibolygatolt, illetöleg széthányt sírokkal kapesolatban is tapasztalatokat gyüjthessek. A széthányt esontok helyzeto alapján ugyanis a következöket figyelhettem meg:

1. A sírgöđör ásásakor talált esontokat, legalább is a nagyobbakat (koponyát, hosszúesontokat) szép rendlbe, egy esomóba az új sírgï. dörbe, jobb vagy baloldalt az újonnan eltemetett mellé rakták. Többnyire a sírgödör jołb alsó sarkába, a lábszár melló tették ezeket (4. ké p G: azt a csontvázat, amely mollett a csonthalon fekszik, térd felett szintén elvágták egy újabb temetkezéskor).

2. Más esetben a sirásás közben talált esontvazak contjait oldalt tolták, s íry azok keskeny lielyre összeszoritva mutatkoztak az új váz mellett. Különösen akkor fordult ez elö, amikor az új sírgödör mélysége a régiével egyezett. A lólretolt csontok összefïggése néha még teijesen (4. k é p B), vagy részben felismerhetö volt, gyaliran azonban már teljes összevisszaságban feküdtek.

3. Azt is megfigyelhettem, hogy a talált csontokat, vagy legalábl is egy részüket benne lagyták a síngödörben. Ilyenkor általában nem rendbe helyezték al öket, lianem az ösezegyüjtöit esontokat a koporsó clhelyezéso után, de a gödör betemetése elött mielléhányták. Ezek a csontok tehát még nagyjából a sirrgơdör feneke táján vannak (lásd pl. a 3. képen a 10. sírt).

4. Igen gyakori az is, hogy a sirgödör ásásakor talált esontvázakra netn voltak telintettel, hanem szétvagdosva, szétzúzva kidobálták óket, úgyhogy az ujj sirgödörbe legfennebb annyi került vissza belölük, amennyi a kihányt fôldben maradt. Ezek tehát az új sírgödör különbözö szintjéböl, nagy yészt darabokra törve kerültek elö. - $\mathrm{Az} 1-2$. alatt említetek elsösorban a legrégibb tenetkezések mellett fordultak cló, a 4. alatti pedig a legkésóbli síroknál.

A sírásás közben talált esontokat tehát a különböző korokban másként kezelték. Lz nyilván a\% "isök irántí kegyelet, vagy a halottaktól való félelem megnyilvánulásának az idôk folyamán tớrténö átalaknlását tükrözi vissza.

Célravezetönck látom, hogy a nagy összefüggések vázolása után nébány olyan apróbb megfigyelést és eljárást is közöljek, melyek az egyes sírok feltárásakor adốtak. Míg az elózỏek általánosságban is lozzájárulhatnak a középkori temetók feltárásmódjának kialakításáa hoz, az utóbbiak egyes esetek, melyek nem szükségszerüen ismétlödhetnek a különbözö temetökben.

A sírok mélységének bemérése. A templom elôtti ásatási szclvények folszínćnek említett erös $\mathrm{K}-\mathrm{Ny}$-i lejtése következtében az eredetileg vízszintes aljúra ásott sirgödrökben fekvő esontvázaknál a fej és láb mélységo kiilönböző volt. A sírok mélységének szokásos lyemérésére ebben à ssetben teláit egyetlen adat nem volét elégséges. Vehettem volna egy középértékü szamot - a fej és láb mély- 


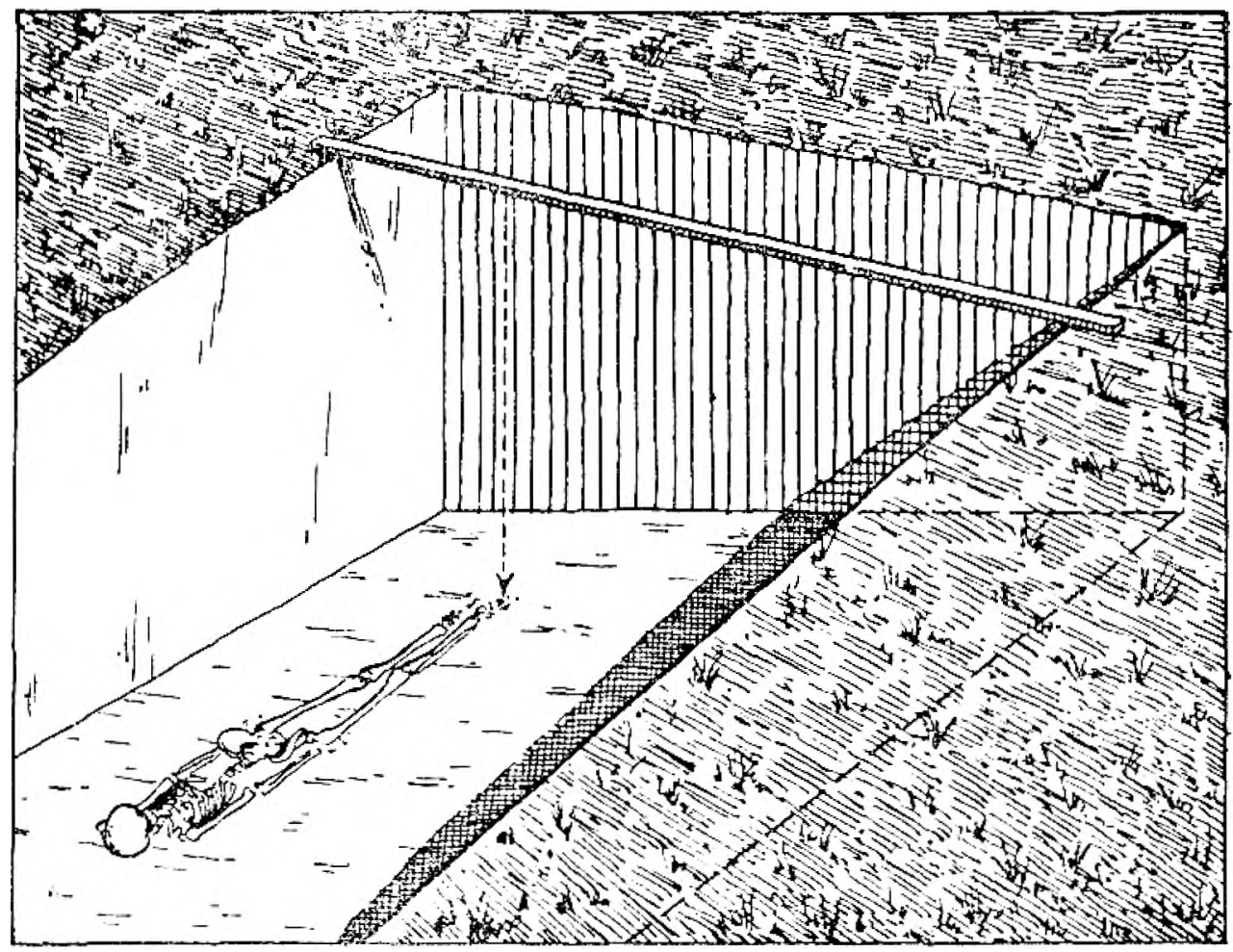

5. kép. A sirok mélységének bemérése lejtős területen

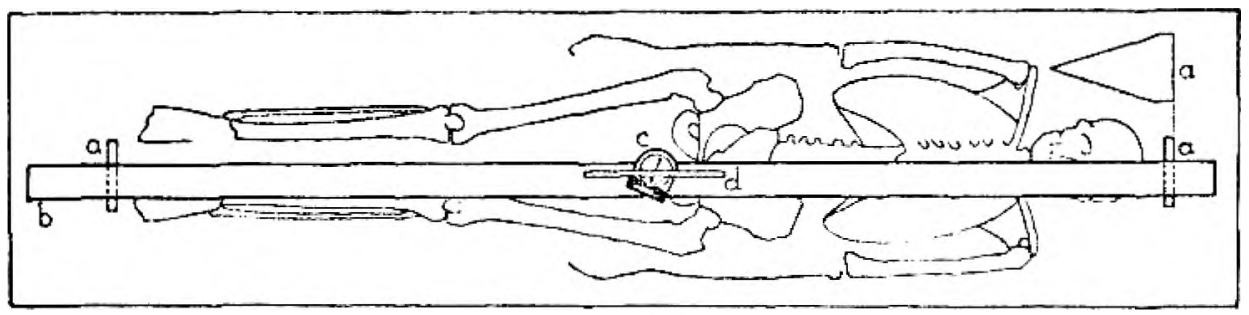

6. Kép. A sirok tájolásáuak bemérésmódia 
ségének középarányosát — de ez nem lett volna hiteles. Ezért minden sírnál két mélységadatot (fej, láb) vettem fel. Ezok segítségével nemcsak a váz pontos mélysíge rögzíthetö, hanem ezckkel az adatoklal egy-egy sir fölött a felszín lejtése is megállapítható.

A sírok mélységének megállapításakor még egy inásils tényezóvel is számolnunk kellett. A sírok mélységét mindig a jelenlegi földfelszíntöl mérjük. Az ásatási szelvényben fekvö esontvázak fölé az elásutt felszint rendes körüulmények között úgy állítjuk vissza, hogy a bemérendó pont fölé vízszintesen az árok szélét átérö lécet fektetünk, s ettöl mérjiik annak mélységét. $\mathrm{Az}$ említett ásatási terület felszíne azonban nemesak $\mathrm{K}-\mathrm{Ny}$ - $\mathrm{i}$ irányban, hanem $\mathrm{E}-\mathrm{D}$-i irányban is lejtett. $\mathrm{A}$ terep ilyen alakulása miatt a $\mathrm{K}-\mathrm{Ny}$-i hossztengelyü szelvény E-i és D-i falának szemközti pontjai nem feküđtek egy szintben. Tehát akármelyik oldal szintjét vettem volna bemérési alapul, a kapott méret nem felelt volna meg a valóságnak. Ilyen esetelkben tellát a mérendő pont felett a szelvény irányára keresztbe fektettem a lécet, melynek vonala igy jelezte a felszin lejtését (5. ké p).

A sírok tájolásának bemérése. A sírok tájolását a szokásos módon mértem be. E mérés pontos és gyakorlatilag könnyen megoldható módja a következó: A koponyához és a lábhoz a váz kơzéptengelyére keresztben egy-egy kihegyezett végü deszkadarabot szúrunk a fơldbe (6. ké p a). Ezekre vízszintesen egy lécet fektetünk, úgy, hogy annak egyik széle a váz középtengelye fơlé essék $(b)$. A lécre helyozett s E-D-i irányra beállítote iránytủ $(c)$ középpontján át a léc szé lével párhuzamosan vonalzót fektetünk $(d)$. A vonalzó iránya mutatja a váz tengelyének az É-D-i iránỵ̂̉l eltérō fokszámát.

A sírok tájolásának beméréséröl még meg kell jegyeznem, hogy tulaj̉donképpen nem a esontvázak, hanem a sírgödrök helyzete az irány. adô. Ezeket ásták ugyanis a világtájak szerint; a halottak viszont nem mindig kerültek a sírgödör tengelyébe, hanem kisebb eltérések tapasztalhalók. $\Lambda$ kidei temetöben a földet - amint láttuk - a megismétlődő temetkezésekkel át- meg átforgatták, a különbözö korú sírok összezsúfolva a legtöbbször egy szintben fekiidtek, ezért sírgödrük alakját és méreteit a legtobb esetben nem állapíthattuk meg; jóformán esals a kevert föld alatti körétegbe belevảgott nehány újabbkori sírgödör méreteit és tájolását figyelhettuik meg. Emiatt a tájolás alapjául egyöntetüség kedvéér't mindeniitt a csontvázak tengelyét vettem, bár egyes sírokban, melyekben a sírgödör formája mellett a koporsó nyomait is megfigyelhettük, legtöbbször a koporsó s így természetesen a benne levö vă sem feküdt a sírgödör tengelyében.

A koporsók bemérés e. A temetó újabbkori sírjaiban a koporsó használatát mindenütt megfigyelhettük. A koporsók azonban a roosszul konzerváló földben elpusztultak, úgyhogy a legkésöbbi sírokban is csak jelentêktelen famaradványokat talâltunk. Ezek tehát a koporsó alakjának helyreállítására elégtelenek voltak. Bármennyire elpusztult is a koporsó, a deszkáit összetartó szegek megmaradtak si ha ezek köziil egyesek a koporsó összeroskadása, vagy a föld nyomása következtében el is csúsztak helyükröl, illetöleg mélyebb szintbe süly- 


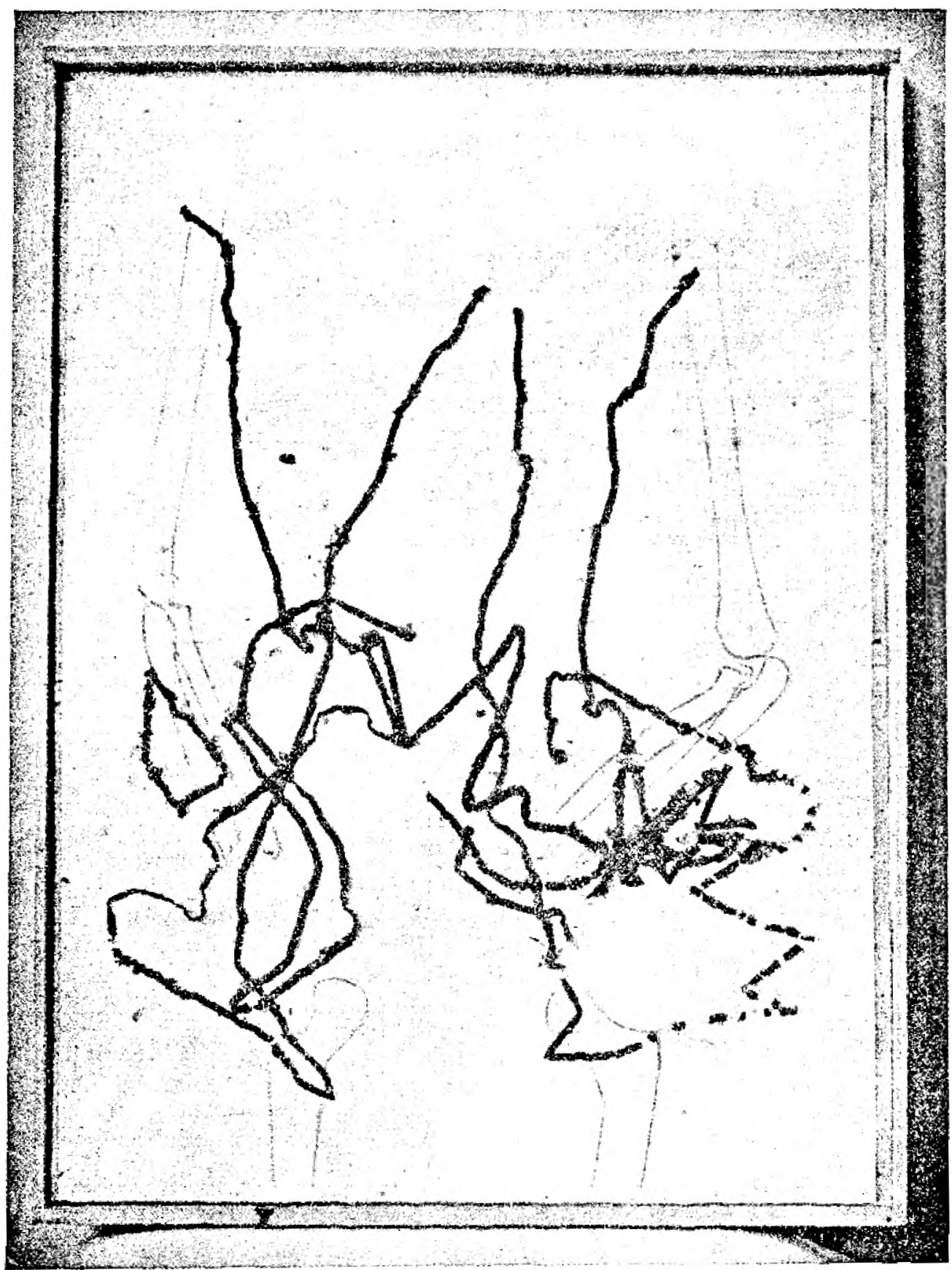

7. kép. Léckeretbe erösített $\mathrm{m} / \mathrm{m}$ papirosra, exedeti fekvésének megfelelóen felragasztot paszomány 
Jyedtek, eredeti jrányukat többnyire megtariották. A kopor'só méreteinek megúllapításához ezeknek a koporsószegeknek a helyzetét vettem alapul. A koporsó összeroskadása folytán nehézségek fóleg csak a koporsó magasságának megállapításában merültek fel.

Beméréseimnél a következöhet tartottam szem elött:

1. A koporsố tetejébe vert szegek függölegesen, fejjel fölfelé állanak.

2. Az oldaläba vert szegek viszont vizszintesen - $\mathrm{s}$ ha csak nem mozdultak el - fejiikkel kifelé állanak.

3. A koporsó aljának szegei hegyïkkel felfelé állnak. Ez utóbbiak mozdulhatnak el legknésbbé helyütkról, mivel fejükkel a sírgödör aljához tapadnak.

A szegeket tehát beverésük helye szerint több szintben találtuk, még akkor is, ha a koporsó összeroskadt.

Mindezeket figyelembe véve, a sír bontása közben legfelïl - többnyire egy szintben - talált szegek helyét a csontvázlapon hozzávetölegesen berajzoltam, fekvését feljegyeztem. Természetesen mielött ezeket a szegeket felszedtủk volna, a esontvázat nagyjảból, vagy ha lehetséges volt teljesen kibontottuk, hogy a szegek helyzetét. a vázhoz viszonyitva rögzíthessiik. Ilyenkor: a magasabb szintben levö szegek alatt keskeny földréteget hagytunk. A felszedett szegek helyére mindenütt vékony fapálcikát szúrtunk \& így haladtunk lefelé a sírfenéken levỏ alsó szegekig. A csontváz felszedése után a szegeknek egymáshoz való viszonyát e fapáleikák alapjân mérôszalaggal rögzítettựk.

A pas z o mán y felszedése. Az egyik XVIII. századi sírban megmaradtak a ruba fémszövésü paszománydarabjai, melyek egymáson keresztül-kasul húzódtak. Ha egyszerüen kiszedtük volna a sírból, többé nem állapítlattuk volna meg. hogy hogyan voltak a ruhára varrva. Ezért helycztïk pontos lerajzolása után eredeti fekvésiuknek megfelelöen szedituik fel öket. Léckeretbe - melyet hátsó felén keresztlécekkel is megszilárdítottunk - kéregpapirt exősitettünk s erre $\mathrm{m} / \mathrm{m}$-papírost ragasztottunk; az utóbbira mérések alapján felvázoltam a csontváz sziikséges részét, s megjelöltem a paszománydarabok pontos helyét. Azután a paszománydarabokat egyenként felszedve, felragasztottuk megfelelö helyükre (7. $\mathrm{k}$ ép). Tyenképpen megmaradt viselettörténeti feldolgozńsának lehetösége.

A pä r ta f els zed ése. Az egyik sírban két gyermekváz feküdt; közülük az egyik oldalfülkében volt. A sirt a sziklás talajba mélyen bevágták s az oldalfiulke bevágása olyan szúk volt, hogy a váz kibontása a legnagyobb nehézségekbe ütközött. A' sírban mellékletek is voltak. A koponya mellett a fülke belsö szögletében egy gyöngyöspárta feküdt, a ruha kézelójének fémes-csipkés kivarrása is megmaradt részben. Mindkettó azonban olyan gyenge állapotban volt, hogy kiemelesük esetén széthullottak volna. Pontos rajzukat sem készíthettem el a helyszínen, mert hozzájuk férni csak hasoncsúszva lehetett. Ezért elhatároztam, hogy gipszburokban kiemelem őket (8. k ép; felïlnézet és metszet). Az eljấrás nem új, de nem tartom sziikségtelennek, hogy a munkamenetet leírjam.

Vastag olajos-szappanhabba mártogatott selyempapír-rétegekkel 


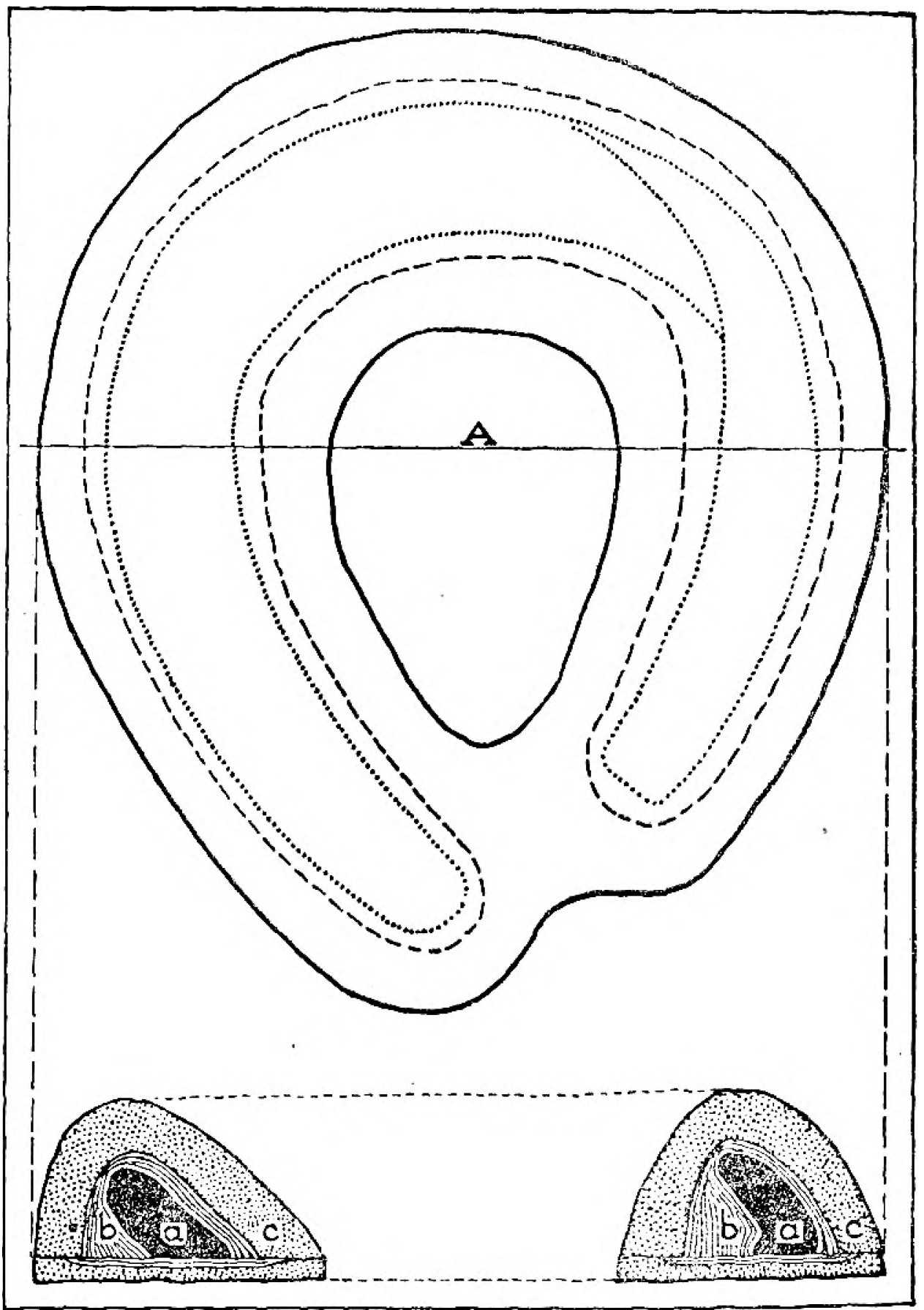

8. $k e ́ p$. Gipsaburokba kiemelt párta felülnézete és metszete (a metszetben: $a=$ párta, $b=$ selyempapirréteg, $e=$ gipszburok) 
fedtül be a pártát és a kézelöket. A nedves papín rétegeket ecsettel jól rányomkodtuk, hogy szorosan tapadjanak a tárgyra (a) s ezältal annak minden részét szilárdan lekössék. A papirrétegek felrakásakor arra is ügyeltünk, hogy a mélyedések mindenuitt kitöltödjonek $s$ a burkolat a fenék felé kơröskörïl szélesedö formát vegyen fel (b). Erre azért volt szükség, hogy a rákerülö gipszburoknak kapaszkodási feliulete sehol so legyen, tehát könnyen leemelhessük, nikor a tárgy kiszabadílására kerüi a sor. Ezután gipszhabaresot (tejfelvastagságút) ké szítettünk, melyet láöntve úgy lormáltunk, hogy egy-másfél ujjinyi rétegben mindenütt fedje a papiriburkolatot $(c)$. A gipsz megkötése (megszilárdulása) után a köves talajra fekvö, feluilról most már szilárdan lerögziteti párta alá lapos sírbontó kaparókat nyomtunk két oldalról, hogy felváljon s ezekkel hirtejen megfordítottuk burkával egyiitt. ${ }^{10}$ A nyitott oldalról is nedves selyempapír-rétegekkel fedve 3-4 mán vastag gipszréteggel zártuk le, hogy a lelet szállítás közben ki ne hulljon.11

E nehriny szerény adattal igyekeztem hozzájárulni, a most még esak kialakulóban levỏ középkorí ásatâstechnikához; ennek terebélyesítéso csakis a tapasztalatok kölesönös kicserélésévol érhetö el.

10 A megfordításiak ezt a módjüt csak kèuyserüsćgböl alkalmaztan. Ha a párta nem kövöt fekszik, akkor nellette körös-körül ferdón rel mélyebb szinthe áshattunk volna s az alatta levó löldréteggel együt gipszburokba fogva emeltük volna $\mathrm{ki}$. Igy ugwanis a megfordítás sokkal veszély telenebb.

11 A lelet kiszabadításakol az alsó vékony réteg eltávolitâsa után a gripszburkot leemeljük, s ha a papíréteg megszáradt volna, újra jól benedvegitve rótegenként leszedjüik. 


\title{
Erdélyi Tudományos Füzetek
}

\author{
Meginditotta Groray Lajoy
}

Szerkeszti Gzahó 'I'. Attilu

12. Gyórty Lalos: Let dialogus regi ma-

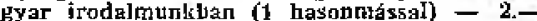

14. Ferenti Mtkl6s: Az erdelyi magyar iradalom bibisografiaja. 1926. év - 1.50

17. Guōrdy Lglos: Egy fillitólagos Pancsataulra-szarmazék irodalmatinkban -

20. Szab6 T. Alllia: Az Erdélyi MizeumEgylel XVI-Xjx. szazadi keziralos bnekesknyvei -------builtal ar erdelyi magyar szellemi dlethes - - - - - - - - -150

23. Kúntor Lajos: Az Erdélyi Mízeum-

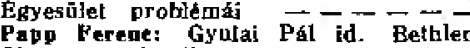

Pápos Frene: Gyulai Pól id. Betblen

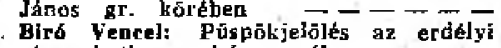
rom. kath. egyhóxmegyéhen - - -

31. Fereneal Mikiós: $\mathrm{Az}$ erdelyi magyar irodalom bibliografieja, 1929 . ev grarorszáson" c regente - - -

6. Szabo T, Atlila: Az Erdelyj Húream Yadad Hegedus-kodere $---\div-1.50$

37. Kéntar Lajos: Hidvegi grol Mikd inre szózata Ifisto-ban ax Erdélyi Muxeum és az Erdélyi Mŕzenm-Egyesōlel meg-

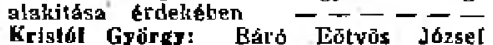
utazásai Erdelyben - - - -

6arga Hela: $A z$ individualités kerdese 2.50

52. Fereuczi Milklós: Az erdélyi magyat irodalom hiolografíaja. 193̈. ev - -

54. Gyorky Lelon: Magyar oneladotionk Naszreddipkapsolalai $-\ldots--\infty 1.50$

55. Veress Endre: Gró Hemeny Jozsel [1795-15j5] (12 keppel) - - - -4

56. Sxabs T. Allita: Adglak Nagyenyed XVI-XX. szazidi bely'teretnek ismeretebex (1 Iertienutraliab)

60. Veress Endre; A törtêterliro Báthot Istyán kiraly (3 képpel) -- -

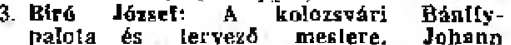

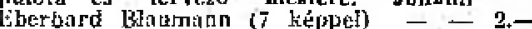

65. Jenesó Elemér: $A z$ icodalomtóttenel-

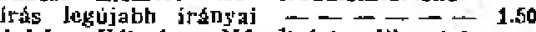

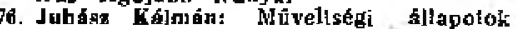
a Temestäzber a török viláchan - 1.20

79. Valenling Antal: $A x$ erdélyj magyar irodajom biblfodtitija. 1934. ev --2

81. Györay Lajes: Anyanyelvän véflelme 1.20

82. Granduierre Edit: A kolozsvari Szenł

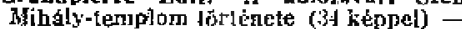

s8. Fess Karals: $A$ mi regénvirodalmunk 2.

99. Valentiny Anlal: Rombizia magyar jro-

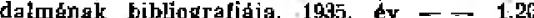

918. Monoki Istrám: Romb́niban az 1955. evben medjelenl roman-magyar es magyar iddstahi sajiotermekel cimjegrzeke $\quad--\ldots-\ldots-\ldots$

92. Joneso Elemer: Nyelv es itrsadalom 1.50

45. Valenling Anlal: Fománia tragyar itodalmáanak bibliográfíaja $193 \hat{k}$. dv -

96. Kúnlot Lajos: Czerei grof Wass Otlilia, az Errely trizenm-Esyestilet

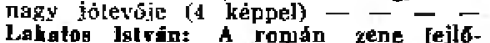
déstôrtente (5 képpet) - - -

100. Györar Lajos: Dr. Bitay Arpad eletrajzi adalai ds tadományos munhássága (1 képpel) - - - - -

10t. Szabo T. Altila: Dés helynevei (2 lét keprdzialta $\rightarrow \ldots-\ldots \ldots \ldots$ -

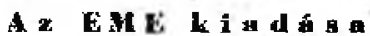

102. Volentiny Anlal: Fomatia magyar jrodalmanal fibliografidja 1937. ex 2104. Szabó T. Altila: Bábony tỏrtênele da teleprílése (68 képpel) - - - - 1. 105. Györg\} Lajas: Az "Erdélyi । Húeum" 㮌rlenele $(1874-1937) \quad---2-$

106. Fublén Bela: Nagukend lelynevei - 1.-

112. Vajenting Anjal: Ramánia magýar irodalmanak bibliografl aja. 1938. ev $-2,2$

114. Sxabo T. Altilg: A haloiaszegi nagybirtokok jobbágyságának czoigalia-

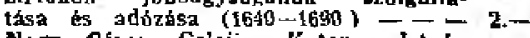

115. Nang Gera: Geleji Katona Istvín személyisége levelé alapján $--\ldots 1,20$

116. Kénlar Lafos: Párbuzatr ez Eadelyi Húzerm-Egyesūlet és az Asłra megalakialásaban es korai túgoudtsebea - 1.50

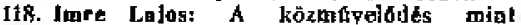
Iársadalmi lelada! - - - - -

f19. Balogh Arlúr: A Netnzeteli Szôvetsége birs évi múkōituséneł mérlege 1.29

120. Gsōrd Lajes: A magyar náboh - - i.50

12L. K. Sebestyén Jáxsel: A Cenk-becri Brasovia vár lemploma i11 képpel) - - 1.

122. Valenfibs Anlak: homania magyar inodalmának bibliogrufjaja, 1939 . eq - 2.-

128. S2gb6 T. Alula: Ujabb adatok \&s po!-

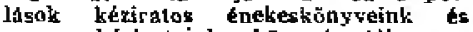
vel'ses kézirataink kōnyvészetébez -1.50

19. Ady Lifalo: Hagvarkapus helyrievei (1 térképyázlatial $\quad-\quad-\ldots$

25. Nyárády E. Gy̆la: Kolozsvár kōroyékéthe niostarvilaga liz képpel es tềrképoul]

t26i. K. Sebesluén Júngef: Répi gzékely

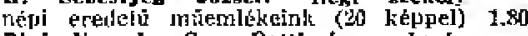

127. Bird Vegeet: Gr. Balthjtay Jgnác (1741-1798) (1 képpel)

129. Ferentzi lalrát Hégeszeli megtigye lésel a dimes dacieus esagknugal szakaczath (12 hejpel) - - - -

130. Herepei Jónas: $A$ dési reforindicus iskola XYjl. é XVHll tzázadbeli igaz-

92. Toth Zol Zoltán: lorga Miklóc es a szé-

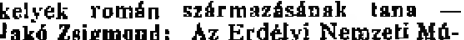

Jakó Ziginmnd: Az Erdelyi Nemzeti Má-

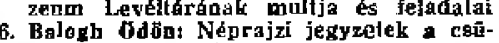
Ré magyarokrbl $----\infty-2.50$

138. Inreh Barna: Werßbánd helynevei - - 3.-

139. Mikó laurt: A Iōrvényhozói ōrszeletrbe-

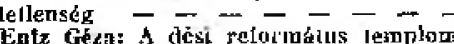
(120 keppej) - - - - Tolnal Gíhor: Grol Lázár János. a Vol-

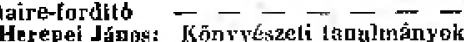
2 keppeh $-\ldots----$

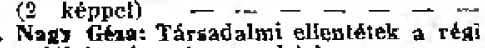
otdélyi református egybázban - - -1.50

147. Szabó T. Altiln: Dés telepälése takosstiga - - - - - - - - - lefki alkala és fejlódése (I kspjel) - 2.50

150. Enix GEza: Snolnok-Dohoka kózépkori múerulékei (9 keppel) - $-\quad-\quad \rightarrow$

154. Vita Zsigmond: Pomdatia magyar irodalmanak bibliografítja r940-ben és 1041-hen - - - _ - - - - 1.50

156. Carda Ferenc; Gr. Kemodny dozsef es Mike Sandor levelezese - - - -2.50

157. Mekbal László: Az ordélyi roțanok a

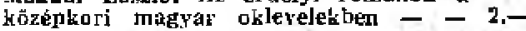

